\title{
Hypoxia uncouples HIF gene transcription and metabolic flux in
} proliferating primary cells

\author{
Courtney A. Copeland ${ }^{1}$, Benjamin A. Olenchock ${ }^{1,2}$, Jamey D. Young ${ }^{3}$, Joseph Loscalzo ${ }^{1}$, William M. Oldham ${ }^{1, *}$ \\ ${ }^{1}$ Department of Medicine, Brigham and Women's Hospital and Harvard Medical School, Boston, MA \\ ${ }^{2}$ Regeneron Pharmaceuticals, Tarrytown, NY \\ ${ }^{3}$ Departments of Chemical \& Biomolecular Engineering and Molecular Physiology \& Biophysics, Vanderbilt University, \\ Nashville, TN
}

${ }^{*}$ Correspondence: William M. Oldham <woldham@bwh.harvard.edu>

\begin{abstract}
Hypoxia is an important environmental stimulus that causes transcriptional and metabolic reprogramming in cells to facilitate their survival. Here, we performed stable isotope tracing and metabolic flux analyses of proliferating primary cells in hypoxia. Despite activation of the hypoxia-inducible factor (HIF) transcriptional program and up-regulation of glycolytic genes, glycolytic flux was decreased in hypoxic cells in our models. No evidence for increased glutaminolysis or reductive carboxylation was observed. While pharmacologic stabilization of HIF in normoxia with the prolyl hydroxylase inhibitor molidustat did increase glycolytic flux as expected, hypoxia abrogated this effect. Together, these data suggest that primary cell bioenergetic metabolism is closely coupled to cell proliferation rate and that other regulatory factors override the effects of HIF-dependent up-regulation of glycolytic gene expression on glycolytic flux.
\end{abstract}

\section{Keywords}

Hypoxia, Metabolic flux analysis, Hypoxia-inducible factor, Prolyl hydroxylase, Metabolism 


\section{Introduction}

Metazoan cells depend on aerobic respiration to meet cellular energy demands. With an inadequate oxygen supply, or hypoxia, cells must reduce energy consumption and shift energy production away from oxidative phosphorylation. Cells accomplish this goal through stabilization of the hypoxia-inducible transcription factor $1 \alpha$ (HIF-1 $\alpha$ ), which activates transcription of glucose transporters, glycolytic enzymes, lactate dehydrogenase, and pyruvate dehydrogenase kinase, while decreasing the expression of proteins in the tricarboxylic acid (TCA) cycle and electron transport chain (Semenza, 2012). Overall, these changes in gene transcription should increase glycolytic capacity and divert glucose-derived pyruvate from oxidative phosphorylation toward lactate fermentation to maintain energy production and minimize the formation of reactive oxygen species (Zhang et al., 2008).

While this "glycolytic shift" of primary carbon metabolism is well-described, the effects of hypoxia on other metabolic pathways are an area of active investigation (Jain et al., 2020). Since hypoxia is a prominent feature of cancer biology as tumor growth outstrips blood supply, most detailed metabolic studies of cell metabolism in hypoxia have used tumor cell models (Wise et al., 2011). For example, stable isotope tracing and metabolic flux analyses identified a critical role for reductive carboxylation of glutamine-derived 2-oxoglutarate for lipid biosynthesis in tumor growth (Gameiro et al., 2013; Metallo et al., 2011; Scott et al., 2011; Wise et al., 2011), and metabolomic studies identified aspartate as a limiting metabolite for cancer cell proliferation under hypoxia (Garcia-Bermudez et al., 2018). By contrast, comparatively little is known about metabolic adaptations of primary cells to hypoxia and the importance of the metabolic pathways described above remain to be elucidated. This information would provide important context for understanding the extent to which cancer cell metabolism responds differently to hypoxic stress. Given the metabolic adaptations required for rapid proliferation in cancer cells, we hypothesized that hypoxia would elicit different metabolic responses in primary cells than has been observed previously in studies of cancer cell metabolism.

To test this hypothesis, we developed models of bioenergetic carbon flux in human primary cells cultured under $21 \%$ or $0.5 \%$ oxygen conditions. We found that hypoxia fails to increase glycolysis in primary cells despite robust up-regulation of the HIF-1 $\alpha$ transcriptional program. In normoxia, HIF-1 $\alpha$ activation by the prolyl hydroxylase inhibitor molidustat (BAY-85-3934, "BAY") (Flamme et al., 2014) did increase glycolysis and lactate efflux; however, hypoxia abrogated this response. These findings suggest the existence of hypoxia-dependent metabolic regulatory mechanisms that override the effects of HIF-1 $\alpha$ dependent up-regulation of glycolytic gene expression. 


\section{Results}

The goal of this study was to identify the metabolic changes associated due to hypoxia in proliferating primary cells. Cells were seeded and placed into hypoxia for $24 \mathrm{~h}$ prior to sample collection to provide adequate time for activation of the hypoxiadependent transcriptional program. From this starting point, we identified the optimal cell seeding density and time course to capture exponential cell growth (Figure 1A), thought to be an indicator of metabolic steady state. Lung fibroblasts cultured in $0.5 \%$ oxygen grew more slowly (Figure 1B), but slower growth was not associated with decreased cell viability (Figure 1C). These cells demonstrated robust stabilization of HIF-1 $\alpha$ protein associated with up-regulation of downstream targets, such as glucose transporter 1, (GLUT1), and lactate dehydrogenase A (LDHA) (Figure 1D-H). These changes persisted for the duration of the experimental time course.

\section{Extracellular metabolite fluxes}

Having established a model system, we next determined the extracellular fluxes of glucose (GLC), lactate (LAC), pyruvate (PYR), and amino acids (Figure 1l-J and Supplementary Figure 1). Flux calculations incorporated the changes in cell number, extracellular metabolite concentrations, and medium evaporation over time (Murphy and Young, 2013) (Supplementary Figure 1). Surprisingly, while glucose uptake was modestly increased in hypoxia, lactate efflux was decreased (Figure 1I) despite activation of the HIF-1 transcriptional program. Similar findings were observed in pulmonary artery smooth muscle cells (Supplementary Figure 1) and when the ambient oxygen level was decreased further to $0.2 \%$ (Supplementary Figure 2). In addition to glucose and lactate, extracellular fluxes of pyruvate and amino acids were generally decreased in hypoxia, including a marked decrease in glutamine uptake. Notably, hypoxia was previously shown to increase glutamine uptake in studies of cancer cell metabolism (Gameiro et al., 2013; Metallo et al., 2011; Wise et al., 2011).

Given that hypoxia did not increase glucose and lactate fluxes as expected from the associated changes in glycolytic gene expression, we next assessed the capacity of HIF-1 $\alpha$ to augment glycolysis in lung fibroblasts. Cells were treated with BAY to stabilize HIF-1 $\alpha$ under $21 \%$ oxygen conditions (Figure 2). Similar to hypoxia, BAY decreased cell growth rate (Figure $2 \mathrm{~A}$ B) and activated the HIF-1 transcriptional program (Figure 2C-G). Compared to hypoxia, BAY treatment resulted in a similar activation of HIF-1 target gene transcription and protein expression. In normoxia, this transcriptional program was associated with increased glucose uptake and lactate efflux (Figure $2 \mathrm{H}$ ). Relatively modest effects on amino acid fluxes were observed as compared to $0.5 \%$ oxygen culture conditions (Figure $2 \mathrm{~J}$ ). 


\section{Stable isotope tracing}

To characterize further the extent of hypoxia-induced metabolic reprogramming, we next treated lung fibroblasts with stable carbon isotopes of glucose and glutamine to trace label incorporation into key carbon utilization pathways (Figure 3 and Supplementary Figure 3). Overall, hypoxia-treated cells had decreased label incorporation into downstream metabolites (i.e., the unlabeled, or M0, fraction was greater). This finding is consistent with the extracellular flux measurements suggesting slower substrate utilization by hypoxic cells. BAY treatment recapitulated the labeling pattern observed with hypoxia, suggesting similar intracellular metabolite flux between these two conditions. Beyond this observation, the labeling patterns in hypoxia- and BAY-treated cells were similar to their respective controls, arguing against marked metabolic reprogramming in response to prolyl hydroxylase inhibition by either hypoxia or BAY. Compared to previous studies of metabolic flux in cancer cells (Metallo et al., 2011; Wise et al., 2011), no hypoxia-mediated increase in M5-labeled citrate from [U- ${ }^{13} C_{5}$ ] glutamine was observed, indicating no increase in reductive carboxylation for lipid synthesis. The overall fraction of M5-citrate in these cells was low $(<6 \%)$.

\section{Metabolic flux analysis}

To clarify changes in intracellular metabolite fluxes, we next generated metabolic flux models incorporating the extracellular flux measurements and tracing data described above. Preliminary labeling time courses indicated that, even after $72 \mathrm{~h}$ of labeling, intracellular metabolites did not reach isotopic steady state (Supplementary Figure 4). Thus, we performed isotopically non-stationary metabolic flux analysis as implemented by INCA (Jazmin and Young, 2013; Murphy et al., 2013; Young, 2014) (Figure 4, Supplementary Figure 4, and Supplementary Tables 3 and 4). Overall, proliferating lung fibroblasts demonstrated high rates of glucose uptake and glycolysis. Approximately $15 \%$ of cytoplasmic pyruvate enters the TCA cycle with the balance converted to lactate. In hypoxia, significant reductions in glycolysis, the TCA cycle, and amino acid metabolism were observed (Figure 4A). To facilitate the identification of differential carbon utilization between treatment groups, metabolite fluxes were normalized to cell growth rate. In this analysis, a modest increase in glycolytic flux is observed (Supplementary Figure 4D). This observation suggests that the effects of the HIF-1 transcriptional program are evident only after adjusting for differences in cell growth rate.

Metabolite fluxes in DMSO-treated cells were similar to $21 \%$ oxygen controls. Compared to hypoxia, BAY treatment was associated with an increase in glycolysis and lactate fermentation in $21 \%$ oxygen, while similar decreases in serine and glutamine incorporation were observed (Figure 4D).

Although the metabolite exchange fluxes for bidirectional reactions tend to be poorly resolved, two observations are worth highlighting (Supplementary Tables 3 and 4). First, consistent with the stable isotope tracing results, the rate of reductive 
carboxylation through reversible flux by isocitrate dehydrogenase is low and unchanged by hypoxia or BAY treatment. Second, hypoxia and BAY treatment are associated with a marked increase in the lactate transport exchange flux (21\%: 9.96e-05 [0-35]; $0.5 \%: 2,950[2,630-3,310] \mathrm{fmol} / \mathrm{cell} / \mathrm{h})$. Since the net lactate transport flux is secretion, this observation suggests increased lactate uptake with hypoxia or BAY treatment. This may be consistent with the HIF-driven increased expression of the reversible lactate transporter MCT4 (Contreras-Baeza et al., 2019). To investigate this hypothesis, lung fibroblasts were treated with $\left[\mathrm{U}_{-}{ }^{13} \mathrm{C}_{3}\right]$ lactate $(2 \mathrm{mM})$ and ${ }^{13} \mathrm{C}$ incorporation into intracellular metabolites was analyzed by LC-MS (Figure 3). Here, we observed increased labeling of TCA metabolites citrate (CIT), 2-oxoglutrate (2OG), malate (MAL), and aspartate (ASP) following hypoxia or BAY treatment (Figure 3 and Supplementary Figure 3). Notably, lactate labeled $\sim 50 \%$ of citrate and $20 \%$ of downstream TCA cycle metabolites, indicating that lactate may be an important respiratory fuel source in these cells even though lactate efflux is high. Although lactate has been used less commonly than glucose and glutamine in stable isotope tracing studies, Faubert and colleagues (2013) demonstrated lactate incorporation in human lung adenocarcinoma in vivo. In this study, lactate incorporation corresponded to regions of high glucose uptake as determined by $\left[{ }^{18} \mathrm{~F}\right]$-fluorodeoxyglucose positron emission tomography, suggesting that lactate consumption can occur in areas of high glucose utilization. In addition to downstream metabolites, we also observed hypoxia- and BAY-dependent increases in lactate incorporation in fructose bisphosphate (FBP) and 3-phosphoglycerate (3PG). This is consistent with prior reports describing hypoxia-mediated increases in glycogen synthesis (Favaro et al., 2012; Pelletier et al., 2012; Pescador et al., 2010). Together, these data suggest that lactate makes a modest ( $10 \%$ carbon) contribution to this process.

\section{Hypoxia abrogates the metabolic effects of prolyl hydroxylase inhibition}

To reconcile the differential effects of prolyl hydroxylase inhibition by hypoxia and BAY, we next addressed whether hypoxia could suppress the effects of BAY on glucose and lactate fluxes (Figure 5). Lung fibroblasts cultured in standard growth medium were treated with BAY and cultured in either $21 \%$ or $0.5 \%$ oxygen. Similar to previous experiments, BAY treatment decreased cell growth rate, increased glucose uptake, and increased lactate efflux in $21 \%$ oxygen. Interestingly, when combined with $0.5 \%$ oxygen, BAY treatment was unable to enhance lactate efflux. These data suggest that hypoxia antagonizes the effects of HIF-1 activation on glycolytic flux in these primary cells. 


\section{Discussion}

In this work, we used ${ }^{13} \mathrm{C}$ metabolic flux analysis to identify hypoxia-mediated metabolic changes in proliferating human primary cells. Our principal finding was that hypoxia reduced, rather than increased, carbon flux through glycolysis and lactate fermentation pathways despite robust activation of the HIF-1 transcriptional program and up-regulation of glycolytic genes. Certainly, our finding that hypoxia was associated with decreased glycolysis and lactate fermentation was unexpected. Several aspects of our experimental design may have contributed to this finding. First, our goal was to understand how metabolic reprogramming may support cell proliferation in hypoxia. Thus, we measured metabolite fluxes in cells during the exponential growth phase accounting for cell growth rate, metabolite degradation rates, and medium evaporation with multiple measurements over a $72 \mathrm{~h}$ time course. Often, cells are studied near confluence, where metabolic contributions to biomass production are less and the rate of glycolysis in hypoxia may be higher. Second, we began our experimental treatments 24 $\mathrm{h}$ prior to collecting samples to ensure that the hypoxia metabolic program was established prior to labeling. Similar studies (Grassian et al., 2014; Metallo et al., 2011) typically placed cells into hypoxia at the time of labeling. Third, and perhaps most importantly, these flux determinations were performed in human primary cell cultures rather than immortalized cell lines.

In addition, we found that hypoxia suppressed the increase in glycolysis induced by HIF-1 $\alpha$ stabilization with the PHD inhibitor BAY. Together, these findings suggest that changes in enzyme levels alone are insufficient to alter metabolic flux in hypoxia and, thus, point to the existence of upstream regulatory mechanisms. Several HIF-independent metabolic regulatory mechanisms may be considered. Hypoxia-mediated activation of AMP-activated protein kinase (AMPK) reduces ATP demand in cells and contributes to cell survival in hypoxia (Dengler, 2020; Wheaton and Chandel, 2011). While the effects of hypoxic AMPK activation on decreasing protein synthesis are well established, direct measurements of the effects of AMPK on metabolic flux in hypoxia are sparse. Marsin and colleagues (2002) demonstrated AMPK-mediated up-regulation of phosphofructokinase-2 and glycolysis in monocytes treated with both hypoxia and LPS, but not with hypoxia alone. Although not hypoxia per se, AMPK inhibition promoted a HIF-1 $\alpha$-dependent metabolic shift to glycolysis in mouse embryonic fibroblasts and E $\mu$-Myc lymphoma cells (Faubert et al., 2013) and, similarly, AMPK activation by AICAR reduced lactate production in tamoxifen-resistant breast cancer cell lines (Woo et al., 2015). These data suggest that AMPK signaling may antagonize the effects of the HIF-1 transcriptional program, although the mechanism for this effect remains to be elucidated. Other HIF-independent pathways may regulate glycolytic flux in hypoxia. These include changes in the activities of other oxygen-dependent enzymes (Islam et al., 2018; Masson et al., 2019), non-HIF targets of PHD enzymes (Winning et al., 2010), and HIF-independent signaling pathways (Arany et al., 2008; Padmanabha et al., 2015). Finally, hypoxia imposes a reductive stress on cells associated with an increase in the NADH/NAD ratio secondary to impaired electron transport (Chance and Williams, 1955; Garofalo et al., 1988). NADH accumulation may slow glycolysis via feedback inhibition of GAPDH (Tilton et al., 1991). Any of these molecular 
mechanisms may contribute to uncoupling glycolytic enzyme expression from glycolytic flux as observed in the experiments described here.

These findings raise important questions regarding the cell-autonomous role of HIFs in the hypoxia response. Certainly, on an organismal level, HIFs drive expression of angiogenic and erythropoietic factors to increase oxygen delivery to hypoxic tissues. Within individual cells, HIF-1 $\alpha$ seems to be important for mitigating the adverse effects of reactive oxygen species (ROS) formation by dysfunctional electron transport in the mitochondria. Indeed, hypoxia increased oxygen consumption and ROS production in HIF-1 $\alpha$-null mouse embryonic fibroblasts (MEFs), which was associated with increased cell death (Zhang et al., 2008). Interestingly, these cells also had increased ATP levels compared to wild type, suggesting that mitochondrial function was adequate under $1 \%$ oxygen culture conditions to support oxidative phosphorylation and meet the energy needs of the cells. Given the prominence of HIFs in mediating the transcriptional response to hypoxia, it is somewhat surprising that none of PHD, HIFs, or their downstream targets were found to be selectively essential as a function of oxygen tension in a genome-wide CRISPR growth screen of cells cultured in normoxia and hypoxia (Jain et al., 2020). In light of our findings, additional studies are warranted to understand the role of HIFs in mediating the metabolic response to hypoxia in primary cells. Moreover, these data strongly caution investigators against drawing conclusions about metabolite flux from measures of gene transcription alone.

In summary, in this metabolic flux analysis of proliferating human primary cells in vitro, we have demonstrated that hypoxia uncouples an increase in HIF-dependent glycolytic gene transcription from glycolytic flux. Indeed, the degree of metabolic reprogramming in hypoxia was modest and suggests close coupling between proliferation and metabolism. Further investigations of metabolic flux in primary cell cultures in hypoxia are warranted to identify the key regulators of metabolism in hypoxia and to clarify the contributions of HIF proteins to hypoxic metabolic reprogramming.

\section{Methods}

Chemicals. Stable isotopes $\left[1,2-{ }^{13} \mathrm{C}_{1}\right]$ glucose, $\left[\mathrm{U}-{ }^{13} \mathrm{C}_{6}\right]$ glucose, $\left[\mathrm{U}-{ }^{13} \mathrm{C}_{5}\right]$ glutamine, and $\left[\mathrm{U}-{ }^{13} \mathrm{C}_{3}\right]$ lactate were purchased from Cambridge Isotope Labs. Molidustat (BAY, BAY-85-3934) was purchased from Cayman.

Cell culture. Commerically available primary human lung fibroblasts and pulmonary artery smooth muscle cells (Lonza) were maintained in FGM-2 or SmGM-2 medium, respectively, without antibiotics (Lonza).

Metabolic flux protocol. For extracellular flux measurements, cells were seeded in MCDB131 medium without glucose, glutamine, or phenol red (genDEPOT) supplemented with $2 \%$ dialyzed fetal bovine serum (Mediatech) and naturally labeled 
glucose ( $8 \mathrm{mM})$ and glutamine (1 $\mathrm{mM})$ ("light" labeling medium). Preliminary experiments were performed to identify the optimal cell seeding density, exponential growth phase, and labeling duration consistent with metabolic and isotopic steady state. For lung fibroblasts, on Day -1, 25,000 cells were seeded in a 35 mm dish in "light" labeling medium. Hypoxia-treated cells were transferred to a tissue culture glovebox set to $0.5 \%$ oxygen and $5 \% \mathrm{CO}_{2}$ (Coy Lab Products). Medium was supplemented with DMSO $0.1 \%$ or BAY $(10 \mu \mathrm{M})$ for these conditions. On Day 0 , cells were washed with PBS and the medium was changed to either "light" medium for flux measurements or "heavy" medium for tracer experiments. Medium and cell lysates were then collected on Days 0-3 for intra- and extracellular metabolite measurements and total DNA quantification. Dishes without cells were weighed daily to correct for evaporative medium losses and to empirically determine degradation and accumulation rates of metabolites. Medium samples and cell lysates for DNA measurement were stored at $-80{ }^{\circ} \mathrm{C}$ until analysis. Each individual experiment included triplicate wells for each treatment and time point, and each experiment was repeated eight times.

Cell count. Direct cell counts of trypsizined cell suspensions in PBS were obtained following staining with propidium iodide and acridine orange using a LUNA-FL fluorescence cell counter (Logos Biosystems). Indirect cell counts for flux measurements were interpolated from total DNA quantified using the Quant-iT PicoGreen dsDNA Assay Kit (Thermo). Cells were washed once with one volume of PBS, lysed with Tris-EDTA buffer containing 2\% Triton X-100, and collected by scraping. Total DNA in $10 \mu \mathrm{L}$ of lysate was determined by adding $100 \mu \mathrm{L}$ of $1 \mathrm{X}$ PicoGreen dye in Tris-EDTA buffer and interpolating the fluorescence intensity with a standard curve generated using the $\lambda$ DNA standard. Cell counts were interpolated from a standard curve of DNA obtained from known cell numbers seeded in basal medium (Supplementary Figure 1A). No difference in total cellular DNA was identified between normoxia and hypoxia cultures (Supplementary Figure 1B).

Immunoblot. Cells were washed with one volume of PBS and collected by scraping in PBS. Cell suspensions were centrifuged at 5,000 $\times g$ for $5 \mathrm{~min}$ at $4{ }^{\circ} \mathrm{C}$. Pellets were lysed in buffer containing Tris $10 \mathrm{mM}, \mathrm{pH}$ 7.4, $\mathrm{NaCl} 150 \mathrm{mM}$, EDTA $1 \mathrm{mM}$, EGTA 1 $\mathrm{mM}$, Triton X-100 1\% v/v, and NP-40 0.5\% v/v containing Halt Protease Inhibitor Cocktail (Thermo). Protein concentrations were determined by BCA Protein Assay (Thermo). Lysates were normalized for protein concentration and subjected to SDSPAGE separation on stain-free tris-glycine gels (Bio-Rad), imaged with the Chemidoc system (Bio-Rad), transferred to PVDF membranes with the Trans-Blot Turbo transfer system (Bio-Rad), imaged, blocked in 5\% blocking buffer (Bio-Rad), blotted in primary and secondary antibodies, and developed using WesternBright ECL (Advansta). Band signal intensity was normalized to total protein per lane as determined from the stain-free gel or membrane images. 
Table 1: Antibodies

\begin{tabular}{lrl}
\hline Protein & Catalog & Manufacturer \\
\hline HIF-1 $\alpha$ & 610958 & BD Biosciences \\
HRP- $\alpha$-Rabbit IgG & 7074 & Cell Signaling Technologies \\
HRP- $\alpha$-Mouse IgG & A4416 & Sigma \\
\hline
\end{tabular}

RT-qPCR. Total RNA was isolated from cells with the RNeasy Mini Kit (Qiagen). cDNA was synthesized from 0.25-1.00 ng RNA with the High Capacity cDNA Reverse Transcription Kit (Applied Biosystems). RT-qPCR analysis was performed with an Applied Biosystems 7500 Fast Real Time PCR System with TaqMan Universal PCR Master Mix and pre-designed TaqMan gene expression assays (Life Technologies). Relative expression levels were calculated using the comparative cycle threshold method referenced to $A C T B$.

Table 2: qPCR Probes

\begin{tabular}{ll}
\hline Gene & ID \\
\hline ACTB & Hs03023943_g1 \\
GLUT1 & Hs00892681_m1 \\
LDHA & Hs00855332_g1 \\
\hline
\end{tabular}

Glucose assay. Medium samples were diluted 10-fold in PBS. Glucose concentration was determined using the Glucose Colorimetric Assay Kit (Cayman) according to the manufacturer's protocol. Standards were prepared in PBS.

Lactate assay. Medium samples were diluted 10 -fold in PBS. Glucose concentration was determined using the L-Lactate Assay Kit (Cayman). Medium samples did not require deproteinization, otherwise the samples were analyzed according to the manufacturer's protocol. Standards were prepared in PBS.

Pyruvate assay. Pyruvate was measured using either an enzymatic assay (most samples) or an HPLC-based assay (medium from $0.2 \%$ oxygen experiments). For the enzymatic assay, medium samples were diluted 20 -fold in PBS. Pyruvate concentration was determined using the Pyruvate Assay Kit (Cayman). Medium samples did not require deproteinization, otherwise the samples were analyzed according to the manufacturer's protocol. Standards were prepared in PBS. For the HPLC assay, 
2-oxovaleric acid was added to medium samples as an internal standard. Samples were subsequently deproteinized with 2 volumes of ice-cold acetone. Supernatants were evaporated to $<50 \%$ of the starting volume at $43^{\circ} \mathrm{C}$ in a SpeedVac concentrator (Thermo Savant) and reconstituted to the starting volume with HPLC-grade water prior to derivatization. Samples were derivatized $1: 1$ by volume with o-phenylenediamine $(25 \mathrm{mM}$ in $2 \mathrm{M} \mathrm{HCl})$ for 30 min at $80^{\circ} \mathrm{C}$. Derivatized pyruvate was separated with a Poroshell HPH C-18 column $(2.1 \times 100 \mathrm{~mm}, 2.7 \mu \mathrm{m})$ on an Infinity II high-performance liquid chromatography system with fluorescence detection of OPD-derivatized $\alpha$-keto acids as described previously (Guarino et al., 2019).

Amino acid assay. Medium amino acid concentrations were determined following the addition of norvaline and sarcosine internal standards and deproteinization with 2 volumes of ice-cold acetone. Supernatants were evaporated to $<50 \%$ of the starting volume at $43{ }^{\circ} \mathrm{C}$ in a SpeedVac concentrator (Thermo Savant) and reconstituted to the starting volume with HPLC-grade water prior to analysis. Amino acids in deproteinized medium were derivatized with o-phthalaldehyde (OPA) and 9-fluorenylmethylchloroformate (FMOC) immediately prior to separation with a Poroshell HPH-C18 column (4.6 $\times 100$ $\mathrm{mm}, 2.7 \mu \mathrm{m}$ ) on an Infinity II high-performance liquid chromatography system with ultraviolet and fluorescence detection of OPA- and FMOC-derivatized amino acids, respectively, according to the manufacturer's protocol (Agilent) (Long, 2017).

Flux calculations. The growth rate $(\mu)$ and flux $(v)$ for each measured metabolite were defined as follows (Murphy and Young, 2013):

$$
\begin{aligned}
& \frac{d X}{d t}=\mu X \\
& \frac{d M}{d t}=-k M+v X
\end{aligned}
$$

where $X$ is the cell density, $k$ is the first-order degradation or accumulation rate, and $M$ is the mass of the metabolite. These equations are solved as follows:

$$
\begin{aligned}
X & =X_{0} e^{\mu t} \\
M e^{k t} & =\frac{v X_{0}}{\mu+k}\left(e^{(\mu+k) t}-1\right)+M_{0}
\end{aligned}
$$

Growth rate $(\mu)$ and cell count at time $0\left(X_{0}\right)$ were determined by robust linear modeling of the logarithm of cell count as a function of time $(t)$. Metabolite mass was calculated from the measured metabolite concentrations and predicted well volume accounting for evaporative losses (Supplementary Figure 1C). First-order degradation and accumulation rates were obtained from robust linear modeling of metabolite mass $v$. time in unconditioned culture medium. Rates that significantly differed from 0 using Student's $t$-test were incorporated into the flux calculations. Final fluxes were obtained by robust linear 
modeling of $M e^{k t}$ versus $\left(e^{(\mu+k) t}-1\right)$ to determine the slope from which $v$ was calculated using equation (4).

Metabolite extraction and liquid chromatography-mass spectrometry. Intracellular metabolites were obtained at every time point after washing $35 \mathrm{~mm}$ wells with 2 volumes of ice-cold PBS and floating on liquid nitrogen. Plates were stored at $-80^{\circ} \mathrm{C}$ until extraction. Metabolites were extracted with $1 \mathrm{~mL} 80 \% \mathrm{MeOH}$ pre-cooled to $-80{ }^{\circ} \mathrm{C}$ containing $10 \mathrm{nmol}\left[\mathrm{D}_{8}\right]$-DL-valine as an internal standard (Cambridge Isotope Labs). Insoluble material was removed by centrifugation at 21,000 $\times g$ for 15 min at $4{ }^{\circ} \mathrm{C}$. The supernatant was evaporated to dryness at $43^{\circ} \mathrm{C}$ using a SpeedVac concentrator (Thermo Savant). Samples were resuspended in $35 \mu \mathrm{L}$ LC-MS-grade water prior to analysis.

LC-MS analysis was performed on a Vanquish ultra-high-performance liquid chromatography system coupled to a $Q$ Exactive orbitrap mass spectrometer by a HESI-II electrospray ionization probe (Thermo). External mass calibration was performed weekly. Metabolite samples $(2.5 \mu \mathrm{L})$ were separated using a ZIC-pHILIC stationary phase $(2.1 \times 150 \mathrm{~mm}, 5 \mu \mathrm{m})$ (Merck). The autosampler temperature was $4{ }^{\circ} \mathrm{C}$ and the column compartment was maintained at $25{ }^{\circ} \mathrm{C}$. Mobile phase A was $20 \mathrm{mM}$ ammonium carbonate and $0.1 \%$ ammonium hydroxide. Mobile phase $B$ was acetonitrile. The flow rate was $0.1 \mathrm{~mL} / \mathrm{min}$. The mobile phase gradient was as follows: $0 \mathrm{~min}, 80 \% \mathrm{~B} ; 5 \mathrm{~min}, 80 \% \mathrm{~B} ; 30 \mathrm{~min}, 20 \% \mathrm{~B} ; 31 \mathrm{~min}, 80 \% \mathrm{~B} ; 42 \mathrm{~min}, 80 \%$ B. Solvent was introduced to the mass spectrometer via electrospray ionization with the following source parameters: sheath gas 40, auxiliary gas 15 , sweep gas 1 , spray voltage $-3.1 \mathrm{kV}$, capillary temperature $275^{\circ} \mathrm{C}$, S-lens RF level 40 , and probe temperature $350{ }^{\circ} \mathrm{C}$. The mass spectrometer was operated in selected ion monitoring mode with an $\mathrm{m} / \mathrm{z}$ window width of 9.0 centered 1.003355-times half the number of carbon atoms in the target metabolite. The resolution was set at 70,000 and AGC target was $1 \times 10^{5}$ ions. Data were acquired and peaks integrated using TraceFinder 4.1 (Thermo). Peak areas were corrected for quadrupole bias as previously described (Kim et al., 2015). Raw mass isotopomer distributions were corrected for natural isotope abundance using a custom R package employing the method of Fernandez, et al. (Fernandez et al., 1996).

Biomass determination. The dry weight of each lung fibroblast was determined to be $\sim 493 \mathrm{pg}$. This value was estimated by washing $3 \times 10^{6}$ cells twice in PBS and thrice in ice-cold acetone prior to drying overnight in a SpeedVac. The composition of the dry cell mass was estimated from the literature (Quek et al., 2010; Sheikh et al., 2005), and stoichiometric coefficients were determined as described (Murphy et al., 2013; Zamorano et al., 2010).

Metabolic flux analysis. Metabolic flux analysis was performed using the elementary metabolite unit-based software package INCA (Young, 2014). Inputs to the model include the chemical reactions and atom transitions of central carbon metabolism, extracellular fluxes, the identity and composition of ${ }^{13} \mathrm{C}$-labeled tracers, and the MIDs of labeled intracellular metabolites. The metabolic network was adapted from previously published networks (Murphy et al., 2013; Vacanti et al., 2014) and comprises 48 reactions representing glycolysis, the pentose phosphate pathway, the tricarboxylic acid cycle, 
anaplerotic pathways, serine metabolism, and biomass synthesis. The network includes seven extracellular substrates (aspartate, cystine, glucose, glutamine, glycine, pyruvate, serine) and five metabolic products (alanine, biomass, glutamate, lactate, lipid). Models were fit using three ${ }^{13} \mathrm{C}$-labeled tracers, $\left[1,2-{ }^{13} \mathrm{C}_{2}\right]$ glucose, $\left[\mathrm{U}-{ }^{13} \mathrm{C}_{6}\right]$ glucose, and $\left[\mathrm{U}-{ }^{13} \mathrm{C}_{5}\right]$ glutamine. The MIDs of twelve metabolites (2-oxoglutarate, 3-phosphoglycerate, alanine, aspartate, citrate, fructose bisphosphate, glutamate, glutamine, lactate, malate, pyruvate, serine) were used to constrain intracellular fluxes. The following assumptions were made:

1. Metabolism was at steady state.

2. Labeled $\mathrm{CO}_{2}$ produced during decarboxylation reactions left the system and did not re-incorporate during carboxylation reactions.

3. Protein turnover occurred at a negligible rate compared to glucose and glutamine consumption.

4. Acetyl-CoA, aspartate, fumarate, malate, oxaloacetate, pyruvate existed in cytosolic and mitochondrial pools. Aspartate and malate were allowed to exchange freely between the compartments.

5. The per cell biomass requirements of proliferating lung fibroblasts were similar to published estimated in other cells (Quek et al., 2010; Sheikh et al., 2005).

6. Dilution of alanine, aspartate, glutamate, glutamine, lactate, and pyruvate was allowed to occur through reversible exchange with unlabeled substrates in the medium as these metabolites were present in unconditioned medium or serum.

7. Succinate and fumarate are symmetric molecules that have interchangeable orientations when metabolized by TCA cycle enzymes.

Flux estimation was repeated a minimum of 50 times from random initial values. Results were subjected to a $\chi^{2}$ statistical test to assess goodness-of-fit. Accurate $95 \%$ confidence intervals were computed for estimated parameters by evaluating the sensitivity of the sum-of-square residuals to parameter variations (Antoniewicz et al., 2006; Murphy et al., 2013).

Data analysis. The raw data and annotated analysis code necessary to reproduce this manuscript are contained in an $\mathrm{R}$ package research compendium available by reasonable request to the authors and will be made publicly available following publication of the manuscript. Data analysis, statistical comparisons, and visualization were performed in R (R Core Team, 2020) using the packages listed below except as noted otherwise above. Experiments included technical and biological replicates as noted above. Outliers were identified using the median absolute deviation approach. Two group comparisons (e.g., $21 \%$ v. $0.5 \%$ oxygen) were performed using Student's $t$-test. Multifactor comparisons (e.g., BAY and oxygen) were performed using linear mixed-effects models with Tukey's post hoc testing. Probability values less than 0.05 were considered 
bioRxiv preprint doi: https://doi.org/10.1101/2020.09.21.306464; this version posted September 21, 2020. The copyright holder for this preprint (which was not certified by peer review) is the author/funder, who has granted bioRxiv a license to display the preprint in perpetuity. It is made available under aCC-BY-NC-ND 4.0 International license.

significant. 
bioRxiv preprint doi: https://doi.org/10.1101/2020.09.21.306464; this version posted September 21, 2020. The copyright holder for this preprint (which was not certified by peer review) is the author/funder, who has granted bioRxiv a license to display the preprint in perpetuity. It is made available under aCC-BY-NC-ND 4.0 International license.

\section{$301 \quad$ Acknowledgements}

This work was supported by grants from the NIH (K08HL128802), American Lung Association, Pulmonary Hypertension Association, and the American Thoracic Society Foundation to W.M.O and from the NIH (U01HG007690, U01HL108630, U54HL119145) and the American Heart Association (D700382, CV-19) to J.L.

\section{Author Contributions}

W.M.O. conceived and designed the analysis. C.A.C., B.A.O., and W.M.O. collected the data. J.D.Y. and W.M.O. contributed data or analysis tools. W.M.O. performed the analysis. W.M.O. drafted the manuscript. All authors participated in interpreting the results and revising the manuscript. All authors approve the final submission.

\section{Declaration of Interests}

The authors declare no competing interests. 


\section{References}

Antoniewicz, M.R., Kelleher, J.K., and Stephanopoulos, G. (2006). Determination of confidence intervals of metabolic fluxes estimated from stable isotope measurements. Metab Eng 8, 324-337.

Arany, Z., Foo, S.Y., Ma, Y., Ruas, J.L., Bommi-Reddy, A., Girnun, G., Cooper, M., Laznik, D., Chinsomboon, J., Rangwala, S.M., et al. (2008). HIF-independent regulation of vegf and angiogenesis by the transcriptional coactivator pgc-1alpha. Nature $451,1008-1012$.

Chance, B., and Williams, G.R. (1955). Respiratory enzymes in oxidative phosphorylation. III. The steady state. J Biol Chem $217,409-427$.

Contreras-Baeza, Y., Sandoval, P.Y., Alarcon, R., Galaz, A., Cortes-Molina, F., Alegria, K., Baeza-Lehnert, F., Arce-Molina, R., Guequen, A., Flores, C.A., et al. (2019). Monocarboxylate transporter 4 (mct4) is a high affinity transporter capable of exporting lactate in high-lactate microenvironments. J Biol Chem 294, 20135-20147.

Dengler, F. (2020). Activation of ampk under hypoxia: Many roads leading to rome. Int J Mol Sci 21, 2428.

Faubert, B., Boily, G., Izreig, S., Griss, T., Samborska, B., Dong, Z., Dupuy, F., Chambers, C., Fuerth, B.J., Viollet, B., et al. (2013). AMPK is a negative regulator of the warburg effect and suppresses tumor growth in vivo. Cell Metab 17, 113-124.

Favaro, E., Bensaad, K., Chong, M.G., Tennant, D.A., Ferguson, D.J., Snell, C., Steers, G., Turley, H., Li, J.L., Gunther, U.L., et al. (2012). Glucose utilization via glycogen phosphorylase sustains proliferation and prevents premature senescence in cancer cells. Cell Metab 16, 751-764.

Fernandez, C.A., Des Rosiers, C., Previs, S.F., David, F., and Brunengraber, H. (1996). Correction of 13 C mass isotopomer distributions for natural stable isotope abundance. J Mass Spectrom 31, 255-262.

Flamme, I., Oehme, F., Ellinghaus, P., Jeske, M., Keldenich, J., and Thuss, U. (2014). Mimicking hypoxia to treat anemia: HIFstabilizer bay 85-3934 (molidustat) stimulates erythropoietin production without hypertensive effects. PLoS One 9, e111838.

Gameiro, P.A., Yang, J., Metelo, A.M., Perez-Carro, R., Baker, R., Wang, Z., Arreola, A., Rathmell, W.K., Olumi, A., LopezLarrubia, P., et al. (2013). In vivo hif-mediated reductive carboxylation is regulated by citrate levels and sensitizes vhl-deficient cells to glutamine deprivation. Cell Metab 17, 372-385. 
Garcia-Bermudez, J., Baudrier, L., La, K., Zhu, X.G., Fidelin, J., Sviderskiy, V.O., Papagiannakopoulos, T., Molina, H., Snuderl, M., Lewis, C.A., et al. (2018). Aspartate is a limiting metabolite for cancer cell proliferation under hypoxia and in tumours. Nat Cell Biol 20, 775-781.

Garofalo, O., Cox, D.W., and Bachelard, H.S. (1988). Brain levels of nadh and nad+ under hypoxic and hypoglycaemic conditions in vitro. J Neurochem 51, 172-176.

Grassian, A.R., Parker, S.J., Davidson, S.M., Divakaruni, A.S., Green, C.R., Zhang, X., Slocum, K.L., Pu, M., Lin, F., Vickers, C., et al. (2014). IDH1 mutations alter citric acid cycle metabolism and increase dependence on oxidative mitochondrial metabolism. Cancer Res 74, 3317-3331.

Guarino, V.A., Oldham, W.M., Loscalzo, J., and Zhang, Y.Y. (2019). Reaction rate of pyruvate and hydrogen peroxide: Assessing antioxidant capacity of pyruvate under biological conditions. Sci Rep 9, 19568.

Islam, M.S., Leissing, T.M., Chowdhury, R., Hopkinson, R.J., and Schofield, C.J. (2018). 2-oxoglutarate-dependent oxygenases. Annu Rev Biochem 87, 585-620.

Jain, I.H., Calvo, S.E., Markhard, A.L., Skinner, O.S., To, T.L., Ast, T., and Mootha, V.K. (2020). Genetic screen for cell fitness in high or low oxygen highlights mitochondrial and lipid metabolism. Cell 181, 716-727 e11.

Jazmin, L.J., and Young, J.D. (2013). Isotopically nonstationary 13C metabolic flux analysis. Methods Mol Biol 985, 367-390.

Jiang, L., Shestov, A.A., Swain, P., Yang, C., Parker, S.J., Wang, Q.A., Terada, L.S., Adams, N.D., McCabe, M.T., Pietrak, B., et al. (2016). Reductive carboxylation supports redox homeostasis during anchorage-independent growth. Nature 532, 255-258.

Kim, D., Fiske, B.P., Birsoy, K., Freinkman, E., Kami, K., Possemato, R.L., Chudnovsky, Y., Pacold, M.E., Chen, W.W., Cantor, J.R., et al. (2015). SHMT2 drives glioma cell survival in ischaemia but imposes a dependence on glycine clearance. Nature 520, 363-367.

Lee, P., Chandel, N.S., and Simon, M.C. (2020). Cellular adaptation to hypoxia through hypoxia inducible factors and beyond. Nat Rev Mol Cell Biol 21, 268-283.

Lee, W.D., Mukha, D., Aizenshtein, E., and Shlomi, T. (2019). Spatial-fluxomics provides a subcellular-compartmentalized view of reductive glutamine metabolism in cancer cells. Nat Commun 10, 1351. 
Long, W. (2017). Automated amino acid analysis using an agilent poroshell hph-c18 column. Application Note, Agilent Technologies, Inc. Publication Number 5991-5571EN, 1-10.

Marsin, A.S., Bouzin, C., Bertrand, L., and Hue, L. (2002). The stimulation of glycolysis by hypoxia in activated monocytes is mediated by amp-activated protein kinase and inducible 6-phosphofructo-2-kinase. J Biol Chem 277, 30778-30783.

Masson, N., Keeley, T.P., Giuntoli, B., White, M.D., Puerta, M.L., Perata, P., Hopkinson, R.J., Flashman, E., Licausi, F., and Ratcliffe, P.J. (2019). Conserved n-terminal cysteine dioxygenases transduce responses to hypoxia in animals and plants. Science 365, 65-69.

Melendez-Rodriguez, F., Urrutia, A.A., Lorendeau, D., Rinaldi, G., Roche, O., Bogurcu-Seidel, N., Ortega Muelas, M., MesaCiller, C., Turiel, G., Bouthelier, A., et al. (2019). HIF1alpha suppresses tumor cell proliferation through inhibition of aspartate biosynthesis. Cell Rep 26, 2257-2265 e4.

Metallo, C.M., Gameiro, P.A., Bell, E.L., Mattaini, K.R., Yang, J., Hiller, K., Jewell, C.M., Johnson, Z.R., Irvine, D.J., Guarente, L., et al. (2011). Reductive glutamine metabolism by idh1 mediates lipogenesis under hypoxia. Nature 481, 380-384.

Murphy, T.A., and Young, J.D. (2013). ETA: Robust software for determination of cell specific rates from extracellular time courses. Biotechnol Bioeng 110, 1748-1758.

Murphy, T.A., Dang, C.V., and Young, J.D. (2013). Isotopically nonstationary 13C flux analysis of myc-induced metabolic reprogramming in b-cells. Metab Eng 15, 206-217.

Oldham, W.M., Clish, C.B., Yang, Y., and Loscalzo, J. (2015). Hypoxia-mediated increases in I-2-hydroxyglutarate coordinate the metabolic response to reductive stress. Cell Metab 22, 291-303.

Padmanabha, D., Padilla, P.A., You, Y.J., and Baker, K.D. (2015). A hif-independent mediator of transcriptional responses to oxygen deprivation in caenorhabditis elegans. Genetics 199, 739-748.

Pelletier, J., Bellot, G., Gounon, P., Lacas-Gervais, S., Pouyssegur, J., and Mazure, N.M. (2012). Glycogen synthesis is induced in hypoxia by the hypoxia-inducible factor and promotes cancer cell survival. Front Oncol 2, 18.

Pescador, N., Villar, D., Cifuentes, D., Garcia-Rocha, M., Ortiz-Barahona, A., Vazquez, S., Ordonez, A., Cuevas, Y., Saez-Morales, D., Garcia-Bermejo, M.L., et al. (2010). Hypoxia promotes glycogen accumulation through hypoxia inducible factor (hif)mediated induction of glycogen synthase 1. PLoS One 5, e9644. 
Quek, L.E., Dietmair, S., Kromer, J.O., and Nielsen, L.K. (2010). Metabolic flux analysis in mammalian cell culture. Metab Eng $12,161-171$.

Scott, D.A., Richardson, A.D., Filipp, F.V., Knutzen, C.A., Chiang, G.G., Ronai, Z.A., Osterman, A.L., and Smith, J.W. (2011). Comparative metabolic flux profiling of melanoma cell lines: Beyond the warburg effect. J Biol Chem 286, 42626-42634.

Semenza, G.L. (2012). Hypoxia-inducible factors in physiology and medicine. Cell 148, 399-408.

Sheikh, K., Forster, J., and Nielsen, L.K. (2005). Modeling hybridoma cell metabolism using a generic genome-scale metabolic model of mus musculus. Biotechnol Prog 21, 112-121.

Tilton, W.M., Seaman, C., Carriero, D., and Piomelli, S. (1991). Regulation of glycolysis in the erythrocyte: Role of the lactate/pyruvate and nad/nadh ratios. J Lab Clin Med 118, 146-152.

Vacanti, N.M., Divakaruni, A.S., Green, C.R., Parker, S.J., Henry, R.R., Ciaraldi, T.P., Murphy, A.N., and Metallo, C.M. (2014). Regulation of substrate utilization by the mitochondrial pyruvate carrier. Mol Cell 56, 425-435.

Wheaton, W.W., and Chandel, N.S. (2011). Hypoxia. 2. Hypoxia regulates cellular metabolism. Am J Physiol Cell Physiol 300, C385-93.

Winning, S., Splettstoesser, F., Fandrey, J., and Frede, S. (2010). Acute hypoxia induces hif-independent monocyte adhesion to endothelial cells through increased intercellular adhesion molecule-1 expression: The role of hypoxic inhibition of prolyl hydroxylase activity for the induction of nf-kappa b. J Immunol 185, 1786-1793.

Wise, D.R., Ward, P.S., Shay, J.E., Cross, J.R., Gruber, J.J., Sachdeva, U.M., Platt, J.M., DeMatteo, R.G., Simon, M.C., and Thompson, C.B. (2011). Hypoxia promotes isocitrate dehydrogenase-dependent carboxylation of alpha-ketoglutarate to citrate to support cell growth and viability. Proc Natl Acad Sci U S A 108, 19611-19616.

Woo, Y.M., Shin, Y., Lee, E.J., Lee, S., Jeong, S.H., Kong, H.K., Park, E.Y., Kim, H.K., Han, J., Chang, M., et al. (2015). Inhibition of aerobic glycolysis represses akt/mTOR/hif-1alpha axis and restores tamoxifen sensitivity in antiestrogen-resistant breast cancer cells. PLoS One 10, e0132285.

Young, J.D. (2014). INCA: A computational platform for isotopically non-stationary metabolic flux analysis. Bioinformatics 30 , $1333-1335$. 
Zamorano, F., Wouwer, A.V., and Bastin, G. (2010). A detailed metabolic flux analysis of an underdetermined network of cho cells. J Biotechnol 150, 497-508.

Zhang, H., Bosch-Marce, M., Shimoda, L.A., Tan, Y.S., Baek, J.H., Wesley, J.B., Gonzalez, F.J., and Semenza, G.L. (2008). Mitochondrial autophagy is an hif-1-dependent adaptive metabolic response to hypoxia. J Biol Chem 283, 10892-10903.

\section{Software}

<sorenh@math.aau.dk>, U.H.S.H. (2020). Pbkrtest: Parametric bootstrap and kenward roger based methods for mixed model comparison.

Allaire, J., Xie, Y., McPherson, J., Luraschi, J., Ushey, K., Atkins, A., Wickham, H., Cheng, J., Chang, W., and lannone, R. (2020). Rmarkdown: Dynamic documents for $r$.

Bache, S.M., and Wickham, H. (2014). Magrittr: A forward-pipe operator for $r$.

Bates, D., Mächler, M., Bolker, B., and Walker, S. (2015). Fitting linear mixed-effects models using Ime4. Journal of Statistical Software $67,1-48$.

Bates, D., Maechler, M., Bolker, B., and Walker, S. (2020). Lme4: Linear mixed-effects models using 'eigen' and s4.

Bryan, J. (2016). Cellranger: Translate spreadsheet cell ranges to rows and columns.

Clarke, E., and Sherrill-Mix, S. (2017). Ggbeeswarm: Categorical scatter (violin point) plots.

Garnier, S. (2018). Viridis: Default color maps from 'matplotlib'.

Grolemund, G., and Wickham, H. (2011). Dates and times made easy with lubridate. Journal of Statistical Software 40, 1-25.

Halekoh, U., and Højsgaard, S. (2014). A kenward-roger approximation and parametric bootstrap methods for tests in linear mixed models - the R package pbkrtest. Journal of Statistical Software 59, 1-30.

Henry, L., and Wickham, H. (2020a). Purrr: Functional programming tools.

Henry, L., and Wickham, H. (2020b). Rlang: Functions for base types and core $r$ and 'tidyverse' features. 
Kuznetsova, A., Brockhoff, P.B., and Christensen, R.H.B. (2017). ImerTest package: Tests in linear mixed effects models. Journal of Statistical Software 82, 1-26.

Kuznetsova, A., Bruun Brockhoff, P., and Haubo Bojesen Christensen, R. (2020). LmerTest: Tests in linear mixed effects models.

Lenth, R. (2020). Emmeans: Estimated marginal means, aka least-squares means.

Müller, K., and Wickham, H. (2020). Tibble: Simple data frames.

Neuwirth, E. (2014). RColorBrewer: ColorBrewer palettes.

Oldham, W. (2020a). Mzrtools: Make molecular formulas useful for mass spectrometry.

Oldham, W. (2020b). Wmo: Personal utility functions.

Ooms, J. (2020). Magick: Advanced graphics and image-processing in r.

Pedersen, T.L. (2020a). Ggraph: An implementation of grammar of graphics for graphs and networks.

Pedersen, T.L. (2020b). Patchwork: The composer of plots.

Pedersen, T.L. (2020c). Tidygraph: A tidy api for graph manipulation.

R Core Team (2020). R: A language and environment for statistical computing (Vienna, Austria: R Foundation for Statistical Computing).

Ripley, B. (2020). MASS: Support functions and datasets for venables and ripley's mass.

Robinson, D., and Hayes, A. (2020). Broom: Convert statistical analysis objects into tidy tibbles.

Spinu, V., Grolemund, G., and Wickham, H. (2020). Lubridate: Make dealing with dates a little easier.

Ushey, K. (2020). Renv: Project environments.

Venables, W.N., and Ripley, B.D. (2002). Modern applied statistics with s (New York: Springer). 
Wickham, H. (2016). Ggplot2: Elegant graphics for data analysis (Springer-Verlag New York).

Wickham, H. (2019). Stringr: Simple, consistent wrappers for common string operations.

Wickham, H. (2020a). Forcats: Tools for working with categorical variables (factors).

Wickham, H. (2020b). Tidyverse: Easily install and load the 'tidyverse'.

Wickham, H., and Bryan, J. (2019). Readxl: Read excel files.

Wickham, H., and Bryan, J. (2020). Usethis: Automate package and project setup.

Wickham, H., and Henry, L. (2020). Tidyr: Tidy messy data.

Wickham, H., Hester, J., and Francois, R. (2018). Readr: Read rectangular text data.

Wickham, H., Averick, M., Bryan, J., Chang, W., McGowan, L.D., François, R., Grolemund, G., Hayes, A., Henry, L., Hester, J., et al. (2019). Welcome to the tidyverse. Journal of Open Source Software 4, 1686.

Wickham, H., Hester, J., and Chang, W. (2020a). Devtools: Tools to make developing r packages easier.

Wickham, H., François, R., Henry, L., and Müller, K. (2020b). Dplyr: A grammar of data manipulation.

Wickham, H., Chang, W., Henry, L., Pedersen, T.L., Takahashi, K., Wilke, C., Woo, K., Yutani, H., and Dunnington, D. (2020c). Ggplot2: Create elegant data visualisations using the grammar of graphics.

Wickham, H., Danenberg, P., Csárdi, G., and Eugster, M. (2020d). Roxygen2: In-line documentation for r.

Wilke, C.O. (2019). Cowplot: Streamlined plot theme and plot annotations for 'ggplot2'.

Xie, Y. (2015). Dynamic documents with R and knitr (Boca Raton, Florida: Chapman; Hall/CRC).

Xie, Y. (2016). Bookdown: Authoring books and technical documents with R markdown (Boca Raton, Florida: Chapman; Hall/CRC).

Xie, Y. (2020a). Bookdown: Authoring books and technical documents with $r$ markdown. 
bioRxiv preprint doi: https://doi.org/10.1101/2020.09.21.306464; this version posted September 21, 2020. The copyright holder for this preprint (which was not certified by peer review) is the author/funder, who has granted bioRxiv a license to display the preprint in perpetuity. It is made available under aCC-BY-NC-ND 4.0 International license.

Xie, Y. (2020b). Knitr: A general-purpose package for dynamic report generation in $r$.

Xie, Y. (2020c). Tinytex: Helper functions to install and maintain tex live, and compile latex documents.

Xie, Y., Allaire, J.J., and Grolemund, G. (2018). R markdown: The definitive guide (Boca Raton, Florida: Chapman; Hall/CRC).

Zhu, H. (2019). KableExtra: Construct complex table with 'kable' and pipe syntax. 


\section{Figure Legends}

Figure 1: Extracellular fluxes of lung fibroblasts in hypoxia. (A) Growth curves of lung fibroblasts cultured in $21 \%$ and $0.5 \%$ oxygen. (B) Growth rates were determined by linear fitting of log-transformed growth curves. (C) Cell viability, assessed by acridine orange plus propidium iodide staining, did not differ between $21 \%$ and $0.5 \%$ oxygen culture conditions $(n=3$ technical replicates). (D) Representative immunoblot of lung fibroblast protein lysates collected at the indicated times. (E, F) Relative change in HIF-1 $\alpha$ (E) and LDHA (F) protein levels compared to $21 \%$ oxygen time 0 . (G, H) Relative changes in GLUT1 (G) and LDHA (H) mRNA levels compared to $21 \%$ oxygen time 0. (I, J) Extracellular fluxes of the indicated metabolites. Biological replicates are indicated and the summary data are expressed as the mean \pm SEM $(n=8)$. Comparisons were performed using Student's paired $t$-test. Flux probability values were not corrected for multiple comparisons. Abbreviations as noted in the text.

Figure 2: Prolyl hydroxylase inhibition of lung fibroblasts in normoxia. (A) Growth curves of lung fibroblasts cultured in $21 \%$ oxygen and treated with molidustat (BAY, $10 \mu \mathrm{M}$ ) or vehicle (DMSO, 0.1\%). (B) Growth rates were determined by linear fitting of log-transformed growth curves. (C) Representative immunoblot of lung fibroblast protein lysates collected at the indicated times. (D, E) Relative change in HIF-1 $\alpha$ (D) and LDHA (E) protein levels compared to DMSO time 0. (F, G) Relative changes in GLUT1 (F) and LDHA (G) mRNA levels compared to DMSO time 0. (H, I) Extracellular fluxes of the indicated metabolites. Biological replicates are indicated and the summary data are expressed as the mean \pm SEM $(n=8)$. Comparisons were performed using Student's paired $t$-test. Flux probability values were not corrected for multiple comparisons. Abbreviations as noted in the text.

Figure 3: Mass isotopomer distributions after $\mathbf{7 2} \mathbf{~ h}$ of labeling. lung fibroblasts were labeled with the indicated tracers (glucose $8 \mathrm{mM}$, glutamine $1 \mathrm{mM}$, lactate $2 \mathrm{mM}$ ). Intracellular metabolites were analyzed by LC-MS. Mass isotopomer distributions were adjusted for natural abundance. Data are the mean \pm SEM of 4 biological replicates. FBP, fructose bisphosphate; 3PG, 3-phosphoglycerate; 2OG, 2-oxoglutarate.

Figure 4: Metabolic flux maps of lung fibroblasts. (A) Ratio of metabolic fluxes in $0.5 \%$ oxygen compared to $21 \%$ oxygen. (B) Ratio of metabolic fluxes in cells treated with molidustat (BAY) compared to DMSO vehicle control. Fluxes with nonoverlapping confidence intervals are highlighted to indicate significant changes.

Figure 5: Hypoxia inhibits the effects of HIF-1 $\alpha$ stabilization on glycolysis. Lung fibroblasts were cultured in standard growth medium and treated with molidustat (BAY, $10 \mu \mathrm{M}$ ) or vehicle (DMSO, $0.1 \%$ ) in $21 \%$ or $0.5 \%$ oxygen conditions. (A) Growth rates were determined by linear fitting of log-transformed growth curves. (B, C) Extracellular fluxes of glucose (B) and lactate 
bioRxiv preprint doi: https://doi.org/10.1101/2020.09.21.306464: this version posted September 21. 2020. The copvriaht holder for this preprint (which was not certified by peer review) is the author/funder, who has granted bioRxiv a license to display the preprint in perpetuity. It is made available under aCC-BY-NC-ND 4.0 International license.

(C). Biological replicates are indicated and the summary data are expressed as the mean. Comparisons were performed using a mixed-effects linear model with date as a random effect. Adjusted p-values for the indicated comparisons were determined using Tukey's post hoc test. 


\section{Figures}

A

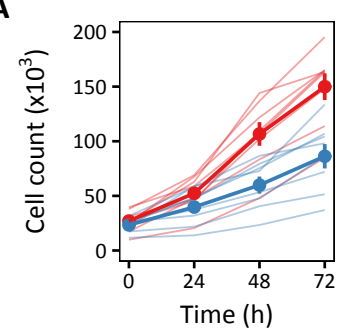

D

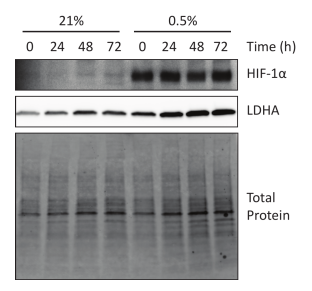

G

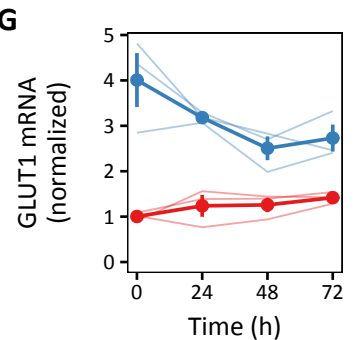

J

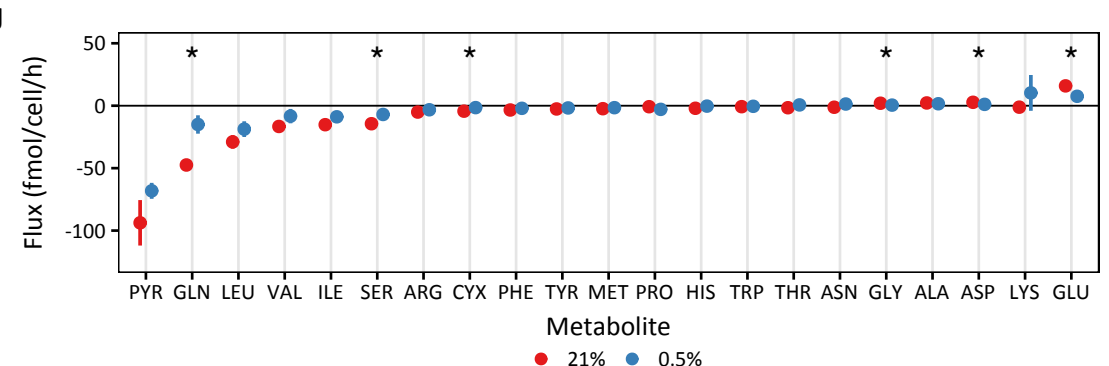

B

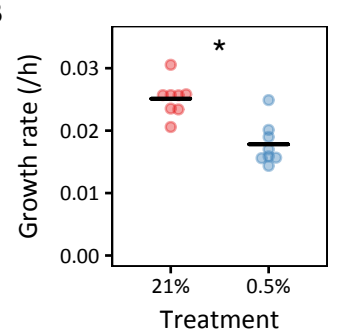

E

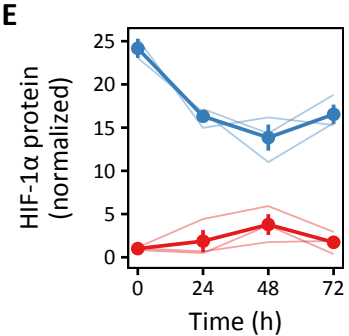

H

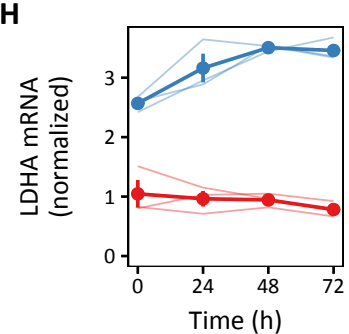

C

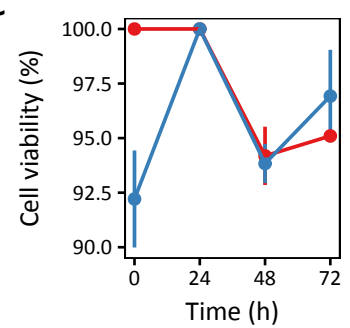

$\mathbf{F}$

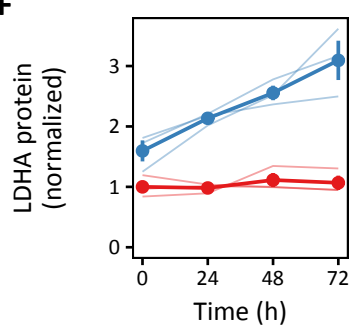

I

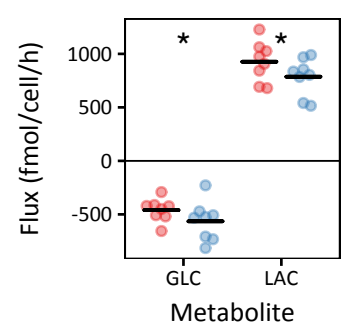

Figure 1: Extracellular fluxes of lung fibroblasts in hypoxia. (A) Growth curves of lung fibroblasts cultured in $21 \%$ and $0.5 \%$ oxygen. (B) Growth rates were determined by linear fitting of log-transformed growth curves. (C) Cell viability, assessed by acridine orange plus propidium iodide staining, did not differ between $21 \%$ and $0.5 \%$ oxygen culture conditions $(n=3$ technical replicates). (D) Representative immunoblot of lung fibroblast protein lysates collected at the indicated times. (E, F) Relative change in HIF-1 $\alpha$ (E) and LDHA (F) protein levels compared to $21 \%$ oxygen time 0 . (G, H) Relative changes in GLUT1 (G) and LDHA (H) mRNA levels compared to $21 \%$ oxygen time $0 .(\mathbf{I}, \mathbf{J})$ Extracellular fluxes of the indicated metabolites. Biological replicates are indicated and the summary data are expressed as the mean \pm SEM $(n=8)$. Comparisons were performed using Student's paired $t$-test. Flux probability values were not corrected for multiple comparisons. Abbreviations as noted in the text. 
A

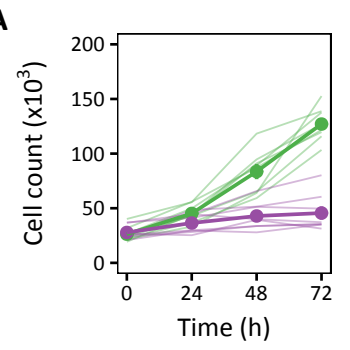

C

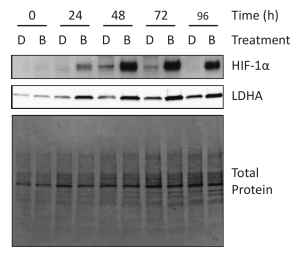

$\mathbf{F}$

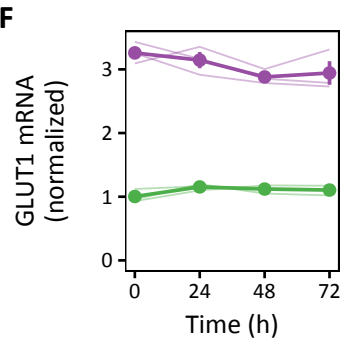

I

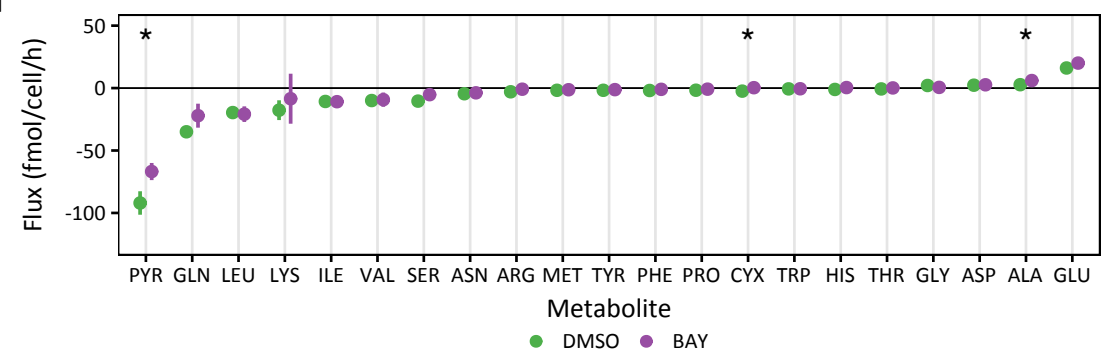

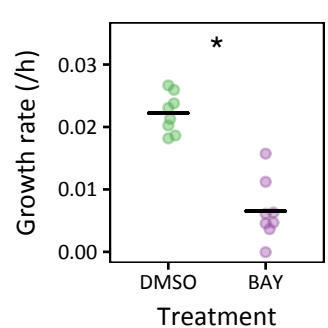

D
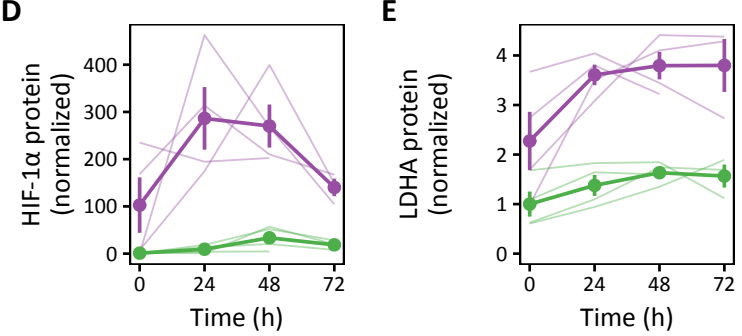

G

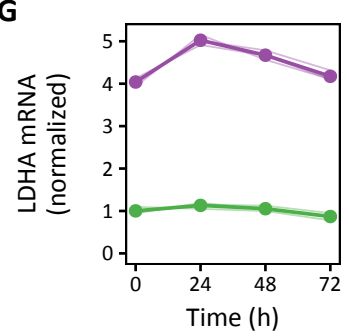

H

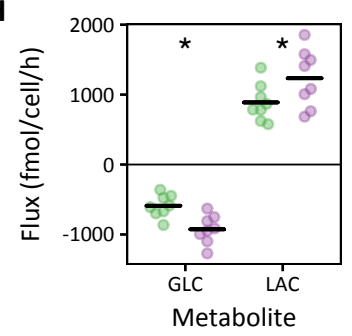

Figure 2: Prolyl hydroxylase inhibition of lung fibroblasts in normoxia. (A) Growth curves of lung fibroblasts cultured in $21 \%$ oxygen and treated with molidustat (BAY, $10 \mu \mathrm{M}$ ) or vehicle (DMSO, 0.1\%). (B) Growth rates were determined by linear fitting of log-transformed growth curves. (C) Representative immunoblot of lung fibroblast protein lysates collected at the indicated times. (D, E) Relative change in HIF-1 $\alpha$ (D) and LDHA (E) protein levels compared to DMSO time 0. $(\mathbf{F}, \mathbf{G})$ Relative changes in GLUT1 (F) and LDHA (G) mRNA levels compared to DMSO time 0. (H, I) Extracellular fluxes of the indicated metabolites. Biological replicates are indicated and the summary data are expressed as the mean $\pm \operatorname{SEM}(n=8)$. Comparisons were performed using Student's paired $t$-test. Flux probability values were not corrected for multiple comparisons. Abbreviations as noted in the text. 
bioRxiv preprint doi: https://doi.org/10.1101/2020.09.21.306464; this version posted September 21, 2020. The copyright holder for this preprint (which was not certified by peer review) is the author/funder, who has granted bioRxiv a license to display the preprint in perpetuity. It is made available under aCC-BY-NC-ND 4.0 International license.

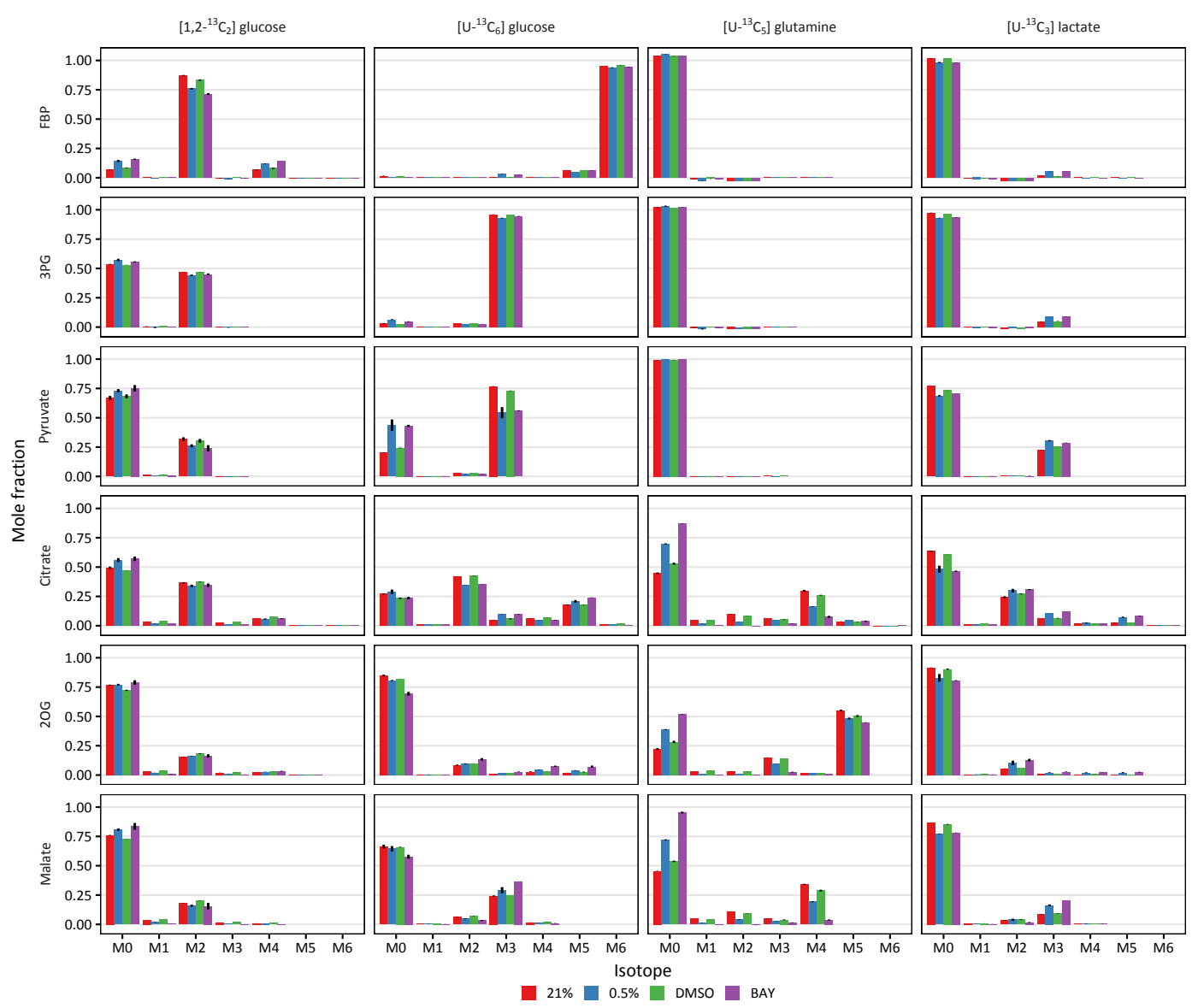

Figure 3: Mass isotopomer distributions after $\mathbf{7 2} \mathbf{~ h}$ of labeling. lung fibroblasts were labeled with the indicated tracers (glucose $8 \mathrm{mM}$, glutamine $1 \mathrm{mM}$, lactate $2 \mathrm{mM}$ ). Intracellular metabolites were analyzed by LC-MS. Mass isotopomer distributions were adjusted for natural abundance. Data are the mean \pm SEM of 4 biological replicates. FBP, fructose bisphosphate; 3PG, 3-phosphoglycerate; 20G, 2-oxoglutarate. 
bioRxiv preprint doi: https://doi.org/10.1101/2020.09.21.306464; this version posted September 21, 2020. The copyright holder for this preprint (which was not certified by peer review) is the author/funder, who has granted bioRxiv a license to display the preprint in perpetuity. It is made available under aCC-BY-NC-ND 4.0 International license.

A

Hypoxia/Normoxia

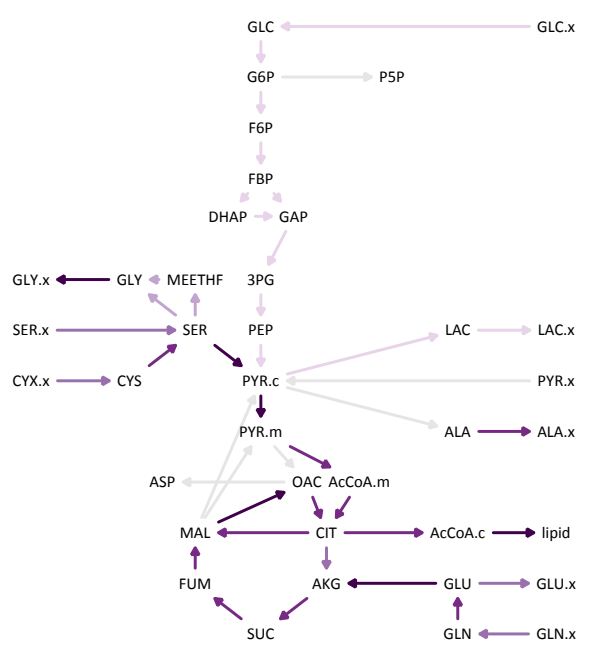

B

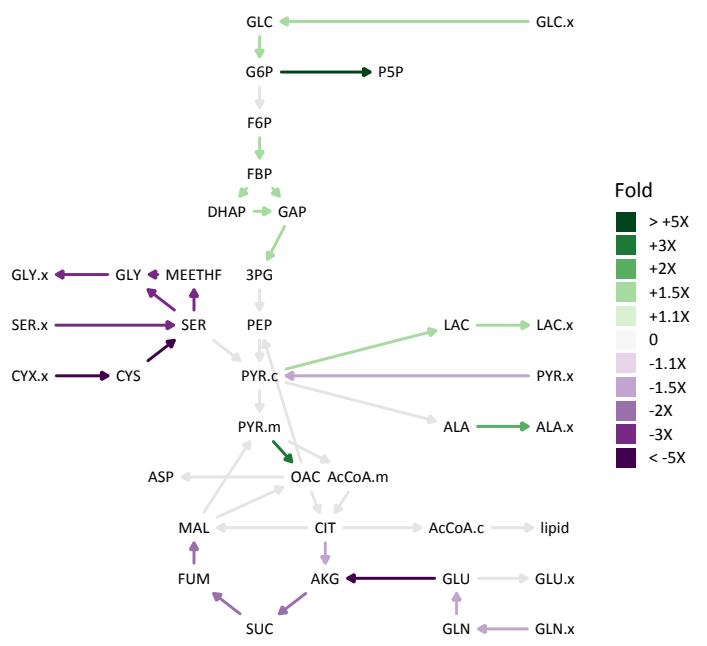

Figure 4: Metabolic flux maps of lung fibroblasts. (A) Ratio of metabolic fluxes in $0.5 \%$ oxygen compared to $21 \%$ oxygen.

(B) Ratio of metabolic fluxes in cells treated with molidustat (BAY) compared to DMSO vehicle control. Fluxes with nonoverlapping confidence intervals are highlighted to indicate significant changes. 
bioRxiv preprint doi: https://doi.org/10.1101/2020.09.21.306464; this version posted September 21, 2020. The copyright holder for this preprint (which was not certified by peer review) is the author/funder, who has granted bioRxiv a license to display the preprint in perpetuity. It is made available under aCC-BY-NC-ND 4.0 International license.
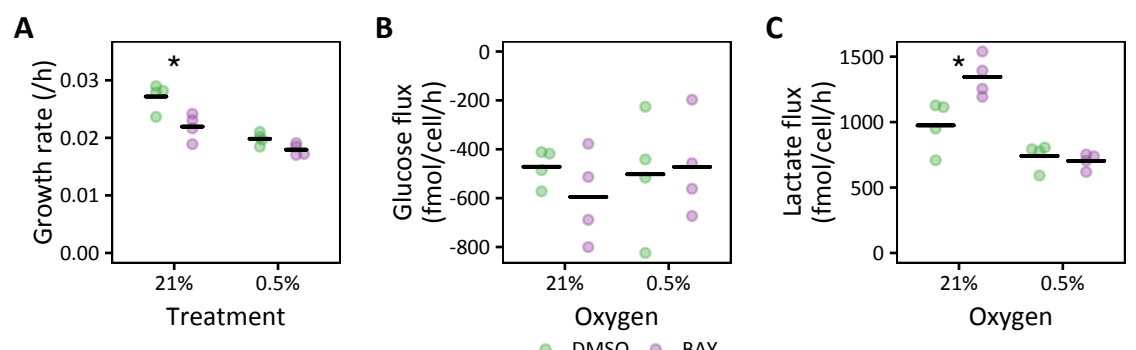

Figure 5: Hypoxia inhibits the effects of HIF-1 $\alpha$ stabilization on glycolysis. Lung fibroblasts were cultured in standard growth medium and treated with molidustat (BAY, $10 \mu \mathrm{M}$ ) or vehicle (DMSO, $0.1 \%$ ) in $21 \%$ or $0.5 \%$ oxygen conditions. (A) Growth rates were determined by linear fitting of log-transformed growth curves. (B, C) Extracellular fluxes of glucose (B) and lactate (C). Biological replicates are indicated and the summary data are expressed as the mean. Comparisons were performed using a mixed-effects linear model with date as a random effect. Adjusted $p$-values for the indicated comparisons were determined using Tukey's post hoc test. 